\title{
ZDOLNOŚCI NUMERYCZNE \\ JAKO KLUCZOWE ZDOLNOŚCI POZNAWCZE \\ W PROCESIE PODEJMOWANIA DECYZJI ${ }^{1}$
}

\author{
Agata Sobków* \\ SWPS Uniwersytet Humanistycznospołeczny
}

\author{
Jakub Figol** \\ SWPS Uniwersytet Humanistycznospołeczny
}

\section{Jakub Traczyk*** \\ SWPS Uniwersytet Humanistycznospołeczny}

Streszczenie: Celem artykułu jest dokonanie przegladu modeli teoretycznych oraz badań empirycznych nad rola zdolności numerycznych (tj. zdolności umystowych $w$ przetwarzaniu informacji numerycznych) $w$ podejmowaniu decyzji $w$ warunkach ryzyka i niepewności. Badania prowadzone $w$ ostatniej dekadzie wskazuja, ze zdolności numeryczne sa jednym z najwazniejszych predyktorów podejmowania dobrych decyzji, którego przewidywania sq niezależne od innych konstruktów psychologicznych oraz zdolności umysłowych (takich jak inteligencja ptynna czy refleksyjność poznawcza). Kluczowa rola zdolności numerycznych jest opisywana $w$ co najmniej trzech modelach teoretycznych: teorii śladu rozmytego, teorii umiejętnego podejmowania decyzji oraz koncepcji wielorakich zdolności numerycznych. Wyniki licznych badan empirycznych wskazuja na to, ze u podtoża podejmowania lepszych decyzji przez osoby z wysokim poziomem zdolności numerycznych leża mechanizmy psychologiczne natury poznawczej, motywacyjnej i afektywnej. Odkrycia dotyczace funkcjonowania osób z wysokim i niskim

\footnotetext{
Przygotowanie tego artykułu zostało sfinansowane z grantu Narodowego Centrum Nauki nr 2018/31/D/ HS6/02899.

* Agata Sobków, Wydział Psychologii we Wrocławiu, Centrum Badań nad Wspieraniem Podejmowania Decyzji, SWPS Uniwersytet Humanistycznospołeczny

** Jakub Figol, Wydział Psychologii we Wrocławiu, Centrum Badań nad Wspieraniem Podejmowania Decyzji, SWPS Uniwersytet Humanistycznospołeczny

*** Jakub Traczyk, Wydział Psychologii we Wrocławiu, Centrum Badań nad Wspieraniem Podejmowania Decyzji, SWPS Uniwersytet Humanistycznospołeczny, e-mail: jtraczyk@swps.edu.pl
} 
poziomem zdolności numerycznych postużyły do opracowania zarówno doraźnych (np. pomoce wizualne lub komunikowanie ryzyka $w$ formacie doświadczeniowym), jak i dtugofalowych (np. treningi poznawcze) metod wspierania procesu podejmowania decyzji. Dzięki tym pomocom decyzyjnym opracowano skuteczne sposoby wspierania osób z niskim poziomem zdolności numerycznych $w$ trafnej ocenie i rozumieniu ryzyka oraz podejmowaniu dobrych decyzji.

Stowa kluczowe: zdolności numeryczne, podejmowanie decyzji, pomoce wizualne, treningi poznawcze, zdolności poznawcze, ocena ryzyka, komunikowanie ryzyka.

\section{ZDOLNOŚCI NUMERYCZNE JAKO KLUCZOWE ZDOLNOŚCI POZNAW- CZE W PROCESIE PODEJMOWANIA DECYZJI}

Abstract: The goal of the present paper is to review recent theoretical models and empirical studies on the role of numeracy (i.e., cognitive ability in processing numerical information) in decision making under risk and uncertainty. The research conducted in the last decade points that numeracy is the most robust predictor of making good decisions, which predictions are independent of other psychological constructs or cognitive abilities (such as fluid intelligence or cognitive reflection). The pivotal role of numeracy has been described in at least three theoretical models: Fuzzy-Trace Theory, Skilled Decision Theory, and Multiple Numeric Competencies model. Furthermore, the results of numerous research indicate that better decisions made by people with high numeracy are underpinned by various psychological mechanisms of the cognitive, motivational, and affective nature. Findings related to the performance of people with high and low numeracy served to develop both immediate (e.g., visual aids or an experience-based format of risk communication) and long-term (e.g., cognitive training) methods of improving the decision-making process. Based on these decision aids, we can effectively support people with low numeracy in an accurate risk assessment, risk comprehension, and making better decisions.

Key words: numeracy, decision making, visual aids, cognitive training, cognitive abilities, risk literacy, risk communication. 


\section{WPROWADZENIE}

Każdego dnia podejmujemy wiele decyzji, które bezpośrednio wiążą się z przetwarzaniem informacji o charakterze numerycznym. Sytuacje decyzyjne, takie jak: wzięcie kredytu, zakup komputera podczas wyprzedaży, podział rachunku za kolację ze znajomymi czy poddanie się eksperymentalnej terapii medycznej z wykorzystaniem nowego leku wymagają przetworzenia informacji liczbowych: o stopie oprocentowania kredytu, cenie po rabacie, kwocie rachunku czy prawdopodobieństwie wystąpienia skutków ubocznych stosowania leku. Niestety, wiele osób (nawet tych dobrze wykształconych) doświadcza poważnych trudności podczas wykonywania podstawowych operacji matematycznych. Na przykład takie osoby nie są w stanie przekształcić informacji wyrażonej w sposób częstościowy na prawdopodobieństwo (np., z formatu „1 na 1000” w format „0,1\%”; Lipkus, Samsa, \& Rimer, 2001; Schwartz, Woloshin, Black, \& Welch, 1997) co w konsekwencji może skutkować większą podatnością na błędy i inklinacje poznawcze oraz zmniejszeniem szansy na podjęcie dobrych decyzji. To jest takich decyzji, które zwiększają prawdopodobieństwo osiągnięcia założonych celów na podstawie spójnego i logicznego przetwarzania dostępnych informacji o problemie decyzyjnym, przy jednoczesnej świadomości ograniczeń związanych z zasobami poznawczymi, dynamiką czasową i złożonością zadania oraz strukturą środowiska decyzyjnego (por. Baron, 2008; Hogarth, 2015; Payne, Bettman, \& Johnson, 1993; Simon, 1990; Vlek, 1984). Dlaczego niektórzy ludzie systematycznie podejmują dobre decyzje, które zwiększają szanse na osiągnięcie zamierzonego celu, podczas gdy inni popełniają błędy w przetwarzaniu informacji numerycznych prowadzące do większej liczby złych wyborów? Jakie czynniki indywidualne mogą wiązać się z podejmowaniem dobrych decyzji? W jaki sposób możemy wspierać podejmowanie dobrych decyzji wśród osób, które często dokonują niewłaściwych wyborów?

W niniejszym artykule postaramy się udzielić odpowiedzi na te pytania, skupiając szczególną uwagę na kluczowej roli zdolności numerycznych (ang. numeracy), tj. zdolności umysłowych w przetwarzaniu informacji numerycznych, w procesie podejmowania decyzji w warunkach ryzyka (np. w badaniach stosujących loterie pieniężne z określonymi prawdopodobieństwami wystąpienia konsekwencji) i warunkach niepewności (np. w badaniach, które wykorzystywały: zadania na podejmowanie decyzji bez podanych prawdopodobieństw konsekwencji, miary unikania negatywnych konsekwencji czy miary behawioralne obserwowane w codziennych sytuacjach). W pierwszej części artykułu przedstawimy najważniejsze modele teoretyczne odnoszące się do różnic indywidualnych w zakresie zdolności numerycznych oraz omówimy mechanizmy (poznawcze, motywacyjne i afektywne), które stoją za podejmowaniem decyzji przez osoby z wysokim poziomem zdolności numerycznych. Dokonamy również przeglądu artykułów prezentujących najważniejsze wyniki badań, które 
wskazują na wartość predykcyjną zdolności numerycznych w przewidywaniu jakości podejmowania decyzji zarówno w klasycznych zadaniach eksperymentalnych (takich jak loterie pieniężne), jak i w codziennym życiu. Zwrócimy tu szczególną uwagę na to, że zdolności numeryczne przewidują podejmowanie decyzji niezależnie od innych miar różnic indywidualnych, takich jak inteligencja płynna czy refleksyjność poznawcza. Na zakończenie wskażemy możliwości zastosowania w praktyce wyników badań nad zdolnościami numerycznymi. Z jednej strony omówimy doraźne metody wspierania podejmowania decyzji, takie jak pomoce wizualne czy metody oparte na doświadczaniu. Ich głównym celem jest transparentne komunikowanie ryzyka w taki sposób, by osoby o niskich zdolnościach numerycznych miały możliwość podejmowania świadomych i „poinformowanych” (ang. informed) decyzji. Z drugiej zaś strony przedstawimy możliwe działania o charakterze długofalowym (takie jak edukacja czy treningi poznawcze), które mają na celu rozwój umiejętności podejmowania decyzji oraz kompetencji w zakresie zdolności numerycznych.

\section{MODELE TEORETYCZNE OPISUJĄCE ROLĘ ZDOLNOŚCI NUMERYCZNYCH}

\section{W PODEJMOWANIU DECYZJI}

Zdolności numeryczne nie są jednorodnym konstruktem psychologicznym. Składają się raczej z kilku względnie niezależnych kompetencji poznawczych, które manifestują się w różnych sposobach przetwarzania informacji numerycznych o problemie decyzyjnym i przewidują odmienne zachowania oraz przekonania na temat tego problemu. Jedną z takich kompetencji, która w ostatnich 10 latach jest intensywnie włączana do badań nad podejmowaniem decyzji, są statystyczne zdolności numeryczne $^{2}$ (Cokely et al., 2018). Statystyczne zdolności numeryczne można zdefiniować jako zdolności poznawcze w zakresie rozumienia informacji statystycznych i probabilistycznych oraz ich praktycznego wykorzystywania w codziennych sytuacjach (Cokely, Galesic, Schult, \& Garcia-Retamero, 2012). Liczne badania wykazały, że tak rozumiane zdolności są ważnym predyktorem podejmowania dobrych decyzji w rozmaitych dziedzinach, od medycyny po finanse (Cokely et al., 2018; Garcia-Retamero, Sobkow, Petrova, Garrido, \& Traczyk, 2019; Reyna, Nelson, Han, \& Dieckmann,

2 W artykule używamy terminu statystyczne zdolności numeryczne w odniesieniu do koncepcji zaproponowanej przez Cokely'a i współpracowników (Cokely et al., 2012) i wyników uzyskiwanych z wykorzystaniem Berlińskiego Testu Zdolności Numerycznych (przykładowa pozycja testowa: „Na 1000 mieszkańców małej wioski 500 jest członkami chóru. Spośród tych 500 członków chóru 100 to mężczyźni. Spośród pozostałych 500 mieszkańców wioski, którzy nie są w chórze, 300 to mężczyźni. Jakie jest prawdopodobieństwo, że losowo wybrany mężczyzna jest członkiem chóru. Prosimy wyrazić prawdopodobieństwo w procentach."). Używamy również terminów zdolności numeryczne lub obiektywne zdolności numeryczne szerzej w odniesieniu do zdolności numerycznych mierzonych innymi podobnymi testami (Lipkus et al., 2001; Schwartz et al., 1997; Weller et al., 2013). 
2009; Sobkow, Garrido, \& Garcia-Retamero, 2020).

Na przykład osoby o wyższych zdolnościach numerycznych, w porównaniu z osobami o niższych zdolnościach numerycznych, podejmują bardziej korzystne decyzje finansowe, gromadząc większy majątek w długoterminowej perspektywie (Estrada-Mejia, de Vries, \& Zeelenberg, 2016; Estrada-Mejia et al., 2020). Związek między posiadanym majątkiem a zdolnościami numerycznymi został zaobserwowany zarówno w nowoczesnym europejskim społeczeństwie (Holandia), w którym ludzie są stosunkowo dobrze wykształceni i mają dostęp do szerokiej gamy produktów finansowych (Estrada-Mejia et al., 2016), jak i w tradycyjnej społeczności Indian Keczua, w której uprawa ziemi jest podstawowym źródłem zarabiania pieniędzy, a za miarę zamożności uznaje się przykładowo posiadanie lodówki czy innych artykułów gospodarstwa domowego (Estrada-Mejia et al., 2020). Co ważne, związki te pozostawały istotne, nawet gdy kontrolowano inne ważne zmienne, takie jak wiedza finansowa, preferencje dotyczące ryzyka, potrzeba poznania, płeć, wiek, wykształcenie i dochód (Estrada-Mejia et al., 2016) lub inteligencja płynna, inteligencja skrystalizowana, wiek, płeć, język ojczysty, związek małżeński i miejsce zamieszkania (Estrada-Mejia et al., 2020).

Wysokie zdolności numeryczne nie wiążą się jedynie z posiadaniem większego majątku. Liczne wyniki badań wskazują, że są one również kluczowe w zakresie podejmowania decyzji medycznych i tych o charakterze prozdrowotnym (Garcia-Retamero \& Cokely, 2017; Garcia-Retamero et al., 2019; Reyna et al., 2009). Osoby o wyższych zdolnościach numerycznych lepiej rozumieją ryzyka i korzyści wynikające ze stosowania różnych terapii czy badań przesiewowych. Dodatkowo, dzięki temu, że pełnią bardziej aktywną rolę w procesie podejmowania decyzji odnośnie własnego zdrowia (np. nie słuchają biernie zaleceń lekarza, ale starają się je zrozumieć i dopasować działania do własnych celów i potrzeb), lepiej przestrzegają zaleceń dotyczących diety czy dawkowania leków. Co istotne, wśród pacjentów o wyższych zdolnościach numerycznych ryzyko występowania zawału mięśnia sercowego lub chorób współistniejących takich jak cukrzyca jest niższe niż wśród pacjentów o niskich zdolnościach numerycznych (Garcia-Retamero, Andrade, Sharit, \& Ruiz, 2015; Petrova, Kostopoulou, Delaney, Cokely, \& Garcia-Retamero, 2018). Związki te pozostają istotne nawet przy kontroli innych ważnych zmiennych, takich jak wiek, wykształcenie czy indeks masy ciała (BMI). Dodatkowo osoby z wyższym poziomem zdolności numerycznych szybciej reagują w sytuacjach, gdy ich zdrowie może być zagrożone. Na przykład mniej zwlekają z uzyskaniem pomocy medycznej w przypadku występowania ostrych zespołów wieńcowych, przejawiających się bólem w klatce piersiowej, co jest bezpośrednio powiązane ze stężeniem troponiny (białka regulującego skurcze mięśnia sercowego), które jest uznawane za wskaźnik zawału serca (Petrova et al., 2017). 
Pojęcie zdolności numerycznych, leżące $u$ ich podstaw mechanizmy poznawcze, a także związki z podejmowaniem decyzji zostały opisane w co najmniej trzech podejściach teoretycznych: teorii śladu rozmytego (ang. Fuzzy-Trace Theory; Broniatowski \& Reyna, 2018; Reyna \& Brainerd, 1995, 2011; Reyna et al., 2009; Reyna, Rahimi-Golkhandan, Garavito, \& Helm, 2018), teorii umiejętnego podejmowania decyzji (ang. Skilled Decision Theory; Cokely et al., 2018) oraz koncepcji wielorakich zdolności numerycznych (ang. Multiple Numeric Competencies; Peters \& Bjälkebring, 2015). Modele te zgodnie podkreślają ważną rolę wyrafinowanych i odnoszących się do osobistych wartości reprezentacji umysłowych problemów decyzyjnych. Reprezentacje te wspierają podejmowanie lepszych decyzji w niepewnym, złożonym i dynamicznym świecie, w którym przetwarzanie oparte na algorytmach nie jest adaptacyjne lub jest niemożliwe do zastosowania.

Teorię śladu rozmytego (Broniatowski \& Reyna, 2018; Reyna \& Brainerd, 1995, 2011; Reyna et al., 2009, 2018) można uznać za szczególny przypadek teorii dualnych procesów przetwarzania informacji. Zgodnie z jej założeniami każda informacja lub zdarzenie są kodowane w pamięci za pomocą dwóch typów reprezentacji umysłowych: verbatim oraz gist. Reprezentacje typu verbatim mogą mieć charakter werbalny lub numeryczny, są precyzyjne i dosłowne. Dotykają jednak jedynie „powierzchni” informacji, pomijając jej istotę. Tego typu reprezentacją posługuje się na przykład osoba, która precyzyjnie nauczyła się „na pamięć” dat, przygotowując się do sprawdzianu z historii. Drugi rodzaj reprezentacji postulowany w teorii śladu rozmytego gist - ma charakter nieprecyzyjny i jakościowy (kategorialny lub porządkowy), oddaje jednak sedno informacji lub sytuacji. Tego typu reprezentacjami posługuje się osoba, która być może nie pamięta precyzyjnej daty danego wydarzenia, ale rozumie jego znaczenie oraz relacje z innymi faktami (np. potrafi umiejscowić je chronologicznie bądź określić, czy dane wydarzenie było korzystne czy niekorzystne dla danej strony).

W kontekście podejmowania decyzji możemy przywołać przykład, w którym osoba dokonuje wyboru między udziałem w loterii, w której ma 50\% szans na wygraną 5 milionów dolarów (i $50 \%$ na to, że nie wygra tej kwoty), a pewnym otrzymaniem 1 miliona dolarów (przykład zaczerpnięty z: Reyna \& Brust-Renck, 2020). W takim wypadku jakościowe reprezentacje typu gist mogą dotyczyć rozróżnienia alternatyw o charakterze „coś albo nic” - w przypadku wyboru drugiej opcji decydent z pewnością otrzyma wypłatę, a w przypadku wyboru pierwszej może zostać z niczym. Gist może mieć również charakter porządkowy. W przywołanym przykładzie opcja pierwsza daje szansę na wyższą wygraną niż opcja druga. Problem decyzyjny może być również przetwarzany w ramach reprezentacji o charakterze verbatim. W takim wypadku osoba nie tylko dostrzega, że pierwsza opcja oferuje wyższą wygraną niż druga opcja, ale również jest w stanie określić, o ile więcej pieniędzy może wygrać, wybierając pierwszą opcję. Dodatkowo tego typu precyzyjne reprezentacje mogą pro- 
wadzić do podejmowania decyzji w oparciu o regułę maksymalizowania wartości oczekiwanej zakładu (tj. poprzez zważenie wypłat pieniężnych przez przypisane do nich prawdopodobieństwa).

Pomimo tego, że reprezentacje typu gist są nieprecyzyjne i opierają się na subiektywnych odczuciach, to w teorii śladu rozmytego są uważane za dojrzałą formę poznania. Autorzy tego modelu teoretycznego podkreślają, że młodsze dzieci lub osoby nieposiadające doświadczenia w danej dziedzinie są bardziej skłonne do używania dosłownych reprezentacji typu verbatim, podczas gdy eksperci i osoby dorosłe są bardziej skłonne do wydobywania właściwego znaczenia sytuacji ( $\mathrm{tj}$. w oparciu o reprezentację typu gist) i korzystania z niego w procesie podejmowania decyzji lub rozwiązywania problemów.

Zgodnie z tą teorią osoby charakteryzujące się wyższymi zdolnościami numerycznymi posiadają wystarczające umiejętności, aby zrozumieć informacje liczbowe zawarte w problemie decyzyjnym (takie jak ryzyko, prawdopodobieństwo, konsekwencje), co pomaga im dojść do sedna problemu (Reyna \& Brainerd, 2008; Reyna \& Brust-Renck, 2014). Osoby o wyższych zdolnościach numerycznych są w większym stopniu skłonne przetwarzać informacje, opierając się na reprezentacjach typu gist, co na ogół jest bardziej adaptacyjne, ale z drugiej strony w pewnych sytuacjach może prowadzić do niekorzystnych inklinacji lub błędów poznawczych (Peters, Fennema, \& Tiede, 2019; Peters et al., 2006; Reyna \& Brust-Renck, 2020).

W podobnym tonie teoria umiejętnego podejmowania Decyzji (Cokely et al., 2018) zakłada, że osoby o wyższych zdolnościach numerycznych zachowują się tak, jakby byli ekspertami w podejmowaniu decyzji w warunkach ryzyka lub niepewności. Cokely i współpracownicy (2018) wyjaśniają, że procesy poznawcze osób z wysokimi zdolnościami numerycznymi są analogiczne do procesów występujących u ekspertów w innych dziedzinach (np. arcymistrzów szachowych). Dzięki nabytemu doświadczeniu takie osoby mają łatwiejszy dostęp do bardziej wyrafinowanych fragmentów wiedzy zmagazynowanej w pamięci długotrwałej (np. oceny pozycji szachowej). W związku z tym nie muszą stosować algorytmicznych reguł decyzyjnych, które aproksymują optymalne rozwiązanie problemu (np. w oparciu o miliony możliwych ruchów do wykonania), lecz opierają się na swojej bogatej wiedzy zorganizowanej w pamięci długotrwałej i stosują rozwiązania, które odpowiadają rozpoznanemu schematowi sytuacji (np. układowi pozycji na szachownicy). W kontekście podejmowania decyzji osoby z wysokim poziomem zdolności numerycznych mają bogatą wiedzę na swój temat (np. o swoich wartościach, preferencjach, doświadczeniach) i mogą wykorzystać tę wiedzę podczas procesu decyzyjnego. Dzięki temu mają możliwość stosowania adaptacyjnych strategii decyzyjnych, które pomagają pokonać wiele ograniczeń wynikających z pojemności pamięci operacyjnej lub złożoności sytuacji. 
Zgodnie z tą teorią (podobnie jak w teorii śladu rozmytego) lepsze funkcjonowanie osób o wysokich zdolnościach numerycznych nie wynika jedynie z precyzyjnego wykonywania obliczeń (np. obliczania wartości oczekiwanej), ale jest raczej rezultatem lepszego zrozumienia problemów decyzyjnych. Badania z wykorzystaniem metody retrospektywnych protokołów werbalnych ${ }^{3}$ wykazały, że osoby o wysokich zdolnościach numerycznych, w porównaniu z osobami o niskich zdolnościach numerycznych, częściej przekształcały strukturę problemu decyzyjnego czy też patrzyły na niego z różnych perspektyw (Cokely \& Kelley, 2009). Na przykład w przypadku problemów loteryjnych, gdzie istniało 5\% szans na wygranie 1600 dolarów, osoby takie zauważały, że mają także $95 \%$ szans na to, że nic nie wygrają (choć taka informacja nie musiała być podana wprost), często skupiały uwagę na porównaniach między najkorzystniejszymi i najmniej korzystnymi wypłatami bądź rozważały ryzyko związane z różnymi opcjami. Podobne werbalizacje zostały ujęte przez badaczy w kategorii nazwanej wyrafinowanym przetwarzaniem heurystycznym (ang. elaborate heuristic search). Podsumowując, osoby z wyższym poziomem zdolności numerycznych mogą wykonywać bardziej skomplikowane operacje matematyczne skutkujące dokonaniem wyboru maksymalizującego wartość oczekiwaną - są bardziej wrażliwe na zmiany wartości oczekiwanej (Jasper, Bhattacharya, Levin, Jones, \& Bossard, 2013; Park \& Cho, 2018). Z drugiej zaś strony mogą opierać się na trafnych heurystykach. W tym sensie mogą dysponować większym repertuarem strategii decyzyjnych, które będą adaptacyjnie stosować w zależności od struktury i wymagań problemu decyzyjnego (Payne, Bettman, \& Johnson, 1988).

Podczas gdy teoria śladu rozmytego koncentruje się głównie na mechanizmach poznawczych, reprezentacjach umysłowych typu gist i verbatim oraz ich zmianach rozwojowych (np. od dzieciństwa do dorosłości), w teorii umiejętnego podejmowania decyzji akcentowany jest aspekt różnic indywidualnych w zdolnościach i umiejętnościach poznawczych. Cokely i współpracownicy (2018) twierdzą, że statystyczne zdolności numeryczne i umiejętność podejmowania decyzji rozszerzają trójwarstwowy model zdolności poznawczych Carrolla (1993). W ramach tego modelu zdolności poznawcze umieszczone zostały na trzech warstwach. W warstwie pierwszej znalazły się wąskie zdolności poznawcze (np. rozumowanie indukcyjne), które z kolei zostały zagnieżdżone w szerokich zdolnościach z warstwy drugiej (np. inteligencji płynnej, pamięci, uczenia się). Trzecia warstwa reprezentuje czynnik nadrzędny - $g$ (inteligencję ogólna). Cokely i współpracownicy (2018) uważają, że zdolności numeryczne i umiejętność podejmowania decyzji powinny być uwzględnione jako niezależny czynnik, w warstwie drugiej, na tym samym poziomie co inteligencja płynna i skrystalizowana. Cokely i współpracownicy (2018) argumentują, że zadania zawarte w testach

3 Metody śledzenia procesów poznawczych, w których osoba badana raportuje werbalnie, jakie operacje poznawcze wykonywała podczas rozwiązywania problemu lub podejmowania decyzji. 
inteligencji płynnej opierają się głównie na wnioskowaniu o charakterze dedukcyjnym, odbywającym się w warunkach pewności. Jednakże zdecydowana większość sytuacji decyzyjnych wiąże się z ryzykiem lub niepewnością i wymaga raczej praktycznego oraz osobiście znaczącego rozumowania indukcyjnego (Cokely et al., 2018).

Hipotezy dotyczące struktury związków między zdolnościami numerycznymi, inteligencją płynną, inteligencją skrystalizowaną i umiejętnością podejmowania decyzji uzyskały wstępne potwierdzenie w danych empirycznych. W badaniu Allan (2018) duża grupa studentów rozwiązała kilka testów mierzących zarówno różne rodzaje umiejętności matematycznych (np. rozumowanie probabilistyczne, algebrę, geometrię), jak i inteligencję płynną, inteligencję skrystalizowaną oraz umiejętność podejmowania decyzji, w której skład wchodziły zarówno loterie pieniężne, zadania sprawdzające odporność na inklinacje poznawcze (np. efekt sformułowania, utopione koszty, nadmierna pewność siebie), jak i trafne ekologicznie zadania dotyczące decyzji medycznych i finansowych. Eksploracyjna analiza czynnikowa wykazała, że zdolności numeryczne należy traktować jako czynnik odrębny od inteligencji płynnej i skrystalizowanej, popierając tym samym ideę rozszerzenia trójwarstwowego modelu zdolności poznawczych Carrolla. Ponadto statystyczne zdolności numeryczne okazały się najlepszą pojedynczą miarą przewidującą ogólną umiejętność podejmowania decyzji (tj. łącznego wyniku ze wszystkich zadań decyzyjnych).

Pomimo wielu podobieństw między tymi dwoma modelami teoretycznymi, różnią się one w kilku ważnych aspektach. Na przykład Reyna i współpracownicy twierdzą, że reprezentacja istoty problemu jest zwykle tworzona przez przetwarzanie o charakterze nieświadomym, z kolei Cokely i współpracownicy (2018) podkreślają kluczową rolę procesów deliberacyjnych. Dodatkowo teoria śladu rozmytego akcentuje zalety nieprecyzyjnego (rozmytego) przetwarzania i poszukiwania najprostszego, ale znaczącego kryterium, które mogłoby pomóc w rozróżnieniu alternatyw i podjęciu decyzji, podczas gdy teoria umiejętnego podejmowania decyzji postuluje, że reprezentacja problemu powinna być szczegółowa i precyzyjna. Wreszcie z tych dwóch teorii wynikają różne praktyczne implikacje dotyczące komunikowania ryzyka. W szczególności teoria śladu rozmytego przewiduje większą skuteczność stosowania komunikatów o charakterze kategorialnym (np. „wystarczy tylko raz”) w celu promowania zachowań prozdrowotnych wśród nastolatków (Reyna et al., 2011). Natomiast Cokely i współpracownicy (2018) argumentują, że komunikat z informacją o ryzyku powinien być tak skonstruowany, by decydent mógł na jego podstawie zbudować osobiście znaczącą reprezentację ryzykownej sytuacji. Autorzy tej koncepcji teoretycznej podkreślają także, że komunikacja ryzyka powinna umożliwić decydentowi podejmowanie świadomych i autonomicznych decyzji. 
Trzeci model teoretyczny (będący raczej taksonomia) różnic indywidualnych w zdolnościach numerycznych został zaproponowany przez Peters i Bjalkebringa (2015). W ramach ich modelu Wielorakich Zdolności Numerycznych oprócz statystycznych zdolności numerycznych (nazywanych tutaj „obiektywnymi zdolnościami numerycznymi") wyróżnione zostały jeszcze dwa rodzaje zdolności numerycznych: szacunkowe zdolności numeryczne i subiektywne zdolności numeryczne (w Tabeli 1 zamieściliśmy przykładowe sposoby pomiaru oraz najważniejsze wyniki badań, które obrazują wartość predykcyjną tych trzech rodzajów zdolności numerycznych).

\section{Tabela 1}

Przyktadowe sposoby pomiaru wielorakich zdolności numerycznych oraz przegląd badań nad rola wielorakich zdolności numerycznych $w$ podejmowaniu decyzji

\begin{tabular}{|c|c|c|}
\hline $\begin{array}{l}\text { Rodzaj zdolności } \\
\text { numerycznych }\end{array}$ & Przykładowa pozycja testowa & Osoby o wysokich zdolnościach.... \\
\hline statystyczne & $\begin{array}{l}\text { Wyobraź sobie, że } 50 \text { razy rzucasz } \\
\text { pięciościenną kostką do gry. } \\
\text { lle razy, średnio, na te } 50 \text { rzutów } \\
\text { wypadnie nieparzysta liczba } \\
(1,3 \text { lub } 5) ?\end{array}$ & $\begin{array}{l}\text { - Adaptacyjne dopasowują strategie do wagi decyzji } \\
\text { (Traczyk, Sobkow, et al., 2018); } \\
\text { - Podejmują normatywnie lepsze decyzje (Ghazal, Cokely, } \\
\text { \& Garcia-Retamero, 2014); } \\
\text { - Stosują przetwarzanie heurystyczne (Cokely \& Kelley, } \\
\text { 2009; Jasper, Bhattacharya, \& Corser, 2017); } \\
\text { - Poszukują więcej informacji w zadaniu decyzji z doświad- } \\
\text { czenia (Ashby, 2017; Traczyk, Lenda, et al., 2018); } \\
\text { - Doświadczają bardziej zróżnicowanych emocji powią- } \\
\text { zanych z problemem decyzyjnym (Peters et al., 2006; } \\
\text { Petrova, van der Pligt, \& Garcia-Retamero, 2014); } \\
\text { - Są mniej podatne na wpływy emocji niezwiązanych } \\
\text { z problemem decyzyjnym (Traczyk \& Fulawka, 2016); } \\
\text { - Posiadają większy majątek (Estrada-Mejia et al., 2016; } \\
\text { Estrada-Mejia et al., 2020); }\end{array}$ \\
\hline subiektywne & $\begin{array}{c}\text { Jak dobry/a jesteś w działaniach } \\
\text { na ułamkach? } \\
1 \text { - Wcale nie jestem dobry/a, } \\
6 \text { - Jestem bardzo dobry/a }\end{array}$ & $\begin{array}{l}\text { - Konsekwentnie stosują bardziej złożone strategie decyzyj- } \\
\text { ne, niezależnie od tego, czy są to problemy o małej czy } \\
\text { dużej wadze (Traczyk, Sobkow, et al., 2018); } \\
\text { - Odczuwają mniej negatywnych emocji, myśląc o zada- } \\
\text { niach matematycznych (Peters \& Bjälkebring, 2015); } \\
\text { - Mogą być nadmiernie pewne siebie i przez to podejmować } \\
\text { gorsze decyzje w codziennych sytuacjach (Peters, Tomp- } \\
\text { kins, et al., 2019; Sobkow, Olszewska, \& Traczyk, 2020); }\end{array}$ \\
\hline szacunkowe & $\begin{array}{l}\text { Na poniższej skali zaznacz wartość } \\
46\end{array}$ & $\begin{array}{l}\text { - Wykazują bardziej liniową funkcję użyteczności (Schley } \\
\text { \& Peters, 2014) oraz wag decyzyjnych (Petrova, Traczyk, } \\
\text { \& Garcia-Retamero, 2019); } \\
\text { - Podejmują decyzje bliższe wartości oczekiwanej (Peters } \\
\text { \& Bjälkebring, 2015; Sobkow, Olszewska, et al., 2020); } \\
\text { - Doświadczają mniejszej liczby negatywnych konsekwencji } \\
\text { decyzji w codziennym życiu (Sobkow, Olszewska, } \\
\text { et al., 2020); } \\
\text { - Mają bardziej wyraziste reprezentacje pamięciowe sytuacji } \\
\text { decyzyjnych (Sobkow, Olszewska, et al., 2020) oraz lepiej } \\
\text { pamiętają dane numeryczne (Peters \& Bjälkebring, 2015). }\end{array}$ \\
\hline
\end{tabular}


W wielu codziennych sytuacjach ludzie prawdopodobnie nie dokonują precyzyjnych obliczeń, a raczej szacują liczebności i wielkości. Na przykład zamiast dokonywać dokładnych obliczeń, szacują, jaki jest w przybliżeniu całkowity koszt ich zakupów w koszyku, ile paliwa muszą zatankować, by dotrzeć do celu, bądź która kolejka do kasy jest najkrótsza. Trafność estymacji w podobnych sytuacjach wiąże się z poziomem szacunkowych zdolności numerycznych.

Szacunkowe zdolności numeryczne można metaforycznie opisać jako „poczucie liczby" - intuicyjną zdolność do postrzegania liczb i manipulowania nimi oraz do mapowania symbolicznych liczb na wielkości. Szacunkowe zdolności numeryczne wywodzą się z idei systemu liczb przybliżonych (ang. Approximate Number System; Campbell, 2005; Dehaene, 1997; Leibovich, Katzin, Harel, \& Henik, 2017) - systemu poznawczego odpowiedzialnego za reprezentowanie i różnicowanie liczebności bez polegania na języku lub symbolach (np. bez polegania na dokładnym liczeniu). System ten jest ewolucyjnie stary i występuje u niemowląt, a nawet u innych ssaków naczelnych (Reynvoet \& Sasanguie, 2016). W systemie liczb przybliżonych liczebności są analogowo reprezentowane w postaci rozkładów aktywacji na niewerbalnej i logarytmicznej mentalnej osi liczbowej (Dehaene, 2003; Izard \& Dehaene, 2008). Rozkłady aktywacji na mentalnej osi liczbowej są przekształcane na określenia werbalne za pomocą siatki odpowiedzi (ang. response grid), a dokładność tego przekształcenia może wskazywać na precyzję mentalnej osi liczbowej (rysunek 1).

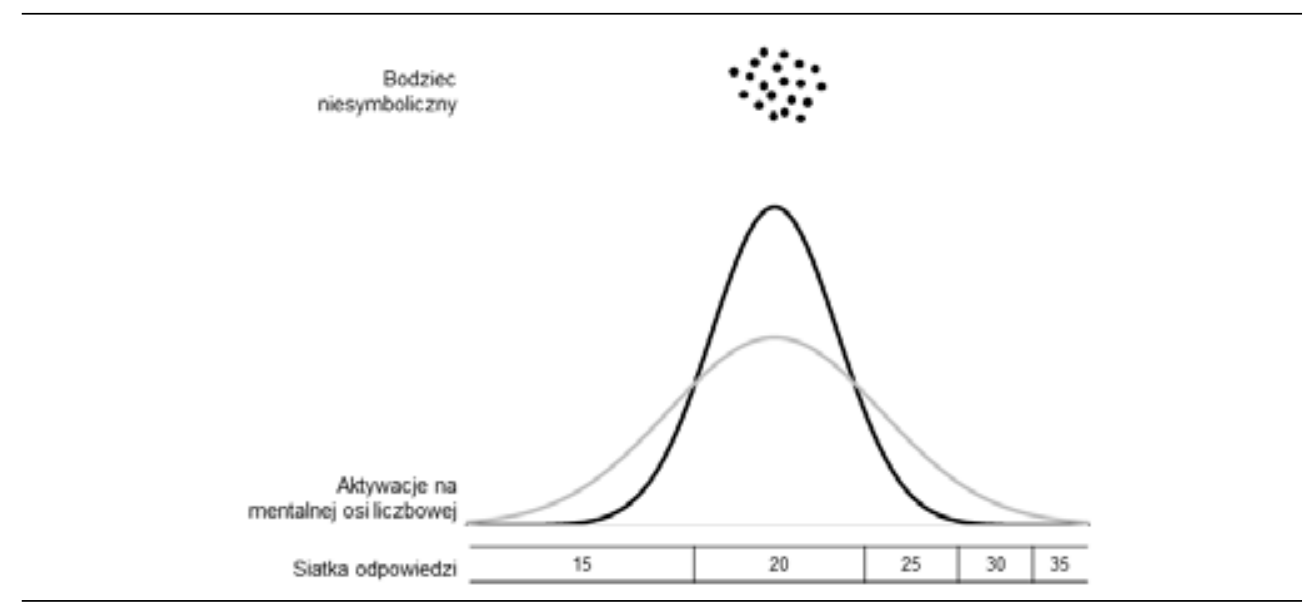

Rysunek 1. Schematyczna ilustracja systemu liczb przybliżonych. Liczebność bodźców (np. 20 kropek w górnej części ilustracji) w postaci niesymbolicznej jest kodowana w postaci rozkładu aktywacji na mentalnej osi liczbowej. Następnie aktywacje te są tłumaczone na etykiety werbalne dla liczb za pomocą siatki odpowiedzi. Osoby o wysokim poziomie szacunkowych zdolności numerycznych (czarna linia) mogą dokonywać tego przekształcenia w sposób bardziej precyzyjny niż osoby z niskimi szacunkowymi zdolnościami numerycznymi (linia szara), ze względu na mniejszą dyspersję rozkładu aktywacji. Zaadaptowano za zgodą (Sobkow et al., 2019) 
Większa precyzja mentalnej osi liczbowej może być utożsamiana z wyższym poziomem szacunkowych zdolności numerycznych. Rezultaty badań wskazują, że precyzja mentalnej osi liczbowej (mierzona za pomocą dokładności w ulokowaniu wartości numerycznych na suwaku o określonej długości) jest związana z podejmowaniem decyzji bliższych modelowi normatywnemu w warunkach ryzyka (Park \& Cho, 2018; Peters \& Bjälkebring, 2015; Sobkow, Fulawka, Tomczak, Zjawiony, \& Traczyk, 2019), oraz z bardziej liniową funkcją wag decyzyjnych (Petrova et al., 2019) i bardziej liniową funkcją użyteczności (Schley \& Peters, 2014). Warto zaznaczyć, że nie oznacza to, iż osoby o wyższych szacunkowych zdolnościach numerycznych spostrzegają wartości liniowo. W ich wypadku funkcja użyteczności jest również S-kształtna zgodnie z przewidywaniami praw psychofizycznych i teorii perspektywy (Kahneman \& Tversky, 1979). Można jednak zauważyć, że u osób, które potrafią precyzyjniej szacować położenie wartości numerycznych na osi liczbowej, funkcja użyteczności estymowana na podstawie wyborów w zadaniu loteryjnym jest mniej wklęsła w przypadku zysków oraz mniej wypukła w przypadku strat w porównaniu z analogicznymi parametrami obliczonymi dla osób o niższych szacunkowych zdolnościach numerycznych.

Ponadto niedawne badania Sobków i współpracowników (Sobkow, Olszewska, et al., 2020) wykazały, że szacunkowe zdolności numeryczne przewidują unikanie negatywnych konsekwencji wyborów nie tylko w klasycznych zadaniach eksperymentalnych (stosujących hipotetyczne loterie pieniężne), ale również w zadaniach mierzących codzienne decyzje (np. kupowanie nowych ubrań, których nigdy się nie założyło lub ogłoszenie upadłości konsumenckiej). Co ważne, szacunkowe zdolności numeryczne były ważnym predyktorem jakości podejmowanych decyzji oraz wyrazistości reprezentacji sytuacji decyzyjnych w pamięci nawet przy kontroli innych zmiennych, w tym inteligencji płynnej, refleksyjności poznawczej, statystycznych zdolności numerycznych i subiektywnych zdolności numerycznych (Sobkow, Olszewska, et al., 2020), co świadczy o względnej niezależności tego konstruktu w przewidywaniu podejmowania decyzji.

Peters i Bjalkebring (2015) jako trzeci rodzaj zdolności numerycznych (obok zdolności obiektywnych/statystycznych i szacunkowych) wyróżnili w swoim modelu subiektywne zdolności numeryczne. Warto tutaj zaznaczyć, że subiektywnych zdolności numerycznych nie należy bezwzględnie traktować jako zdolności poznawczej. Subiektywne zdolności numeryczne odnoszą się raczej do sposobu, w jaki osoba postrzega swój poziom obiektywnych zdolności numerycznych i jaką formę zadań (np. opisowe czy numeryczne) preferuje. Subiektywne zdolności numeryczne są zazwyczaj mierzone za pomocą krótkiego kwestionariusza (Fagerlin et al., 2007). Podczas gdy autorzy tego testu twierdzą, że może on służyć jako pośredni wskaźnik do oceny obiektywnych zdolności numerycznych, ostatnie badania wykazały jednak, że wyniki uzyskiwane w teście subiektywnych zdolności numerycznych mogą przewidywać 
odmienne zachowania i deklaracje od wyników miar obiektywnych zdolności numerycznych. W związku z tym miary te nie powinny być stosowane zamiennie (Dolan, Cherkasky, Li, Chin, \& Veazie, 2016; Låg, Bauger, Lindberg, \& Friborg, 2014; Liberali, Reyna, Furlan, Stein, \& Pardo, 2012).

Subiektywne zdolności numeryczne wiążą się raczej z motywacyjnymi i emocjonalnymi aspektami podejmowania decyzji. Osoby charakteryzujące się wyższym poziomem subiektywnych zdolności numerycznych mogą częściej postrzegać zadania numeryczne jako możliwe do rozwiązania i dlatego mogą wkładać większy wysiłek w ich rozwiązywanie. Na przykład Traczyk i współpracownicy (Traczyk, Sobkow, et al., 2018) wykazali, że wyższy poziom subiektywnych zdolności numerycznych przewidywał wybory maksymalizujące wartość oczekiwaną niezależnie od struktury problemu decyzyjnego (tj. tego, czy dany problem decyzyjny był znaczący czy trywialny z perspektywy potencjalnych wypłat pieniężnych), natomiast statystyczne zdolności numeryczne przewidywały adaptacyjne wykorzystanie strategii decyzyjnych. W problemach znaczących, w których stosunek wartości oczekiwanych dwóch zakładów pieniężnych był wysoki i dzięki temu dobra decyzja mogła przynieść większy zysk, osoby z wyższym poziomem statystycznych zdolności numerycznych maksymalizowały wartość oczekiwaną i dokonywały wyborów zgodnych z przewidywaniami skumulowanej teorii perspektywy (Tversky \& Kahneman, 1992). Jednakże w problemach trywialnych, w których stosunek wartości oczekiwanych był niski i potencjalny zysk w dwóch zakładach pieniężnych był porównywalny niezależnie od podjętej decyzji, osoby takie dokonywały wyborów zgodnych z przewidywaniami prostszej obliczeniowo i mniej angażującej poznawczo heurystyki pierwszeństwa (Brandstätter, Gigerenzer, \& Hertwig, 2006).

Podobne rozbieżności między mocą predykcyjną subiektywnych i obiektywnych zdolności numerycznych zaobserwowano również w dziedzinie medycyny: subiektywne, ale nie obiektywne, zdolności numeryczne wiązały się z chęcią zapłacenia większej kwoty za badania genetyczne w kierunku diagnostyki raka piersi, których interpretacja wymaga radzenia sobie z liczbami (Miron-Shatz, Hanoch, Doniger, Omer, \& Ozanne, 2014). Wreszcie w swoich badaniach Peters i Bjalkebring (2015) wykazali, że subiektywne zdolności numeryczne były adekwatną miarą obiektywnych zdolności numerycznych w odniesieniu do tylko jednej miary: zarówno osoby o wysokich obiektywnych, jak i subiektywnych zdolnościach numerycznych podawały wyceny loterii pieniężnych bliższe ich wartościom oczekiwanym.

Subiektywne i obiektywne zdolności numeryczne nie tylko pozwalają przewidywać podejmowanie decyzji w różny sposób, ale dodatkowo wchodzą ze sobą w interakcję w przewidywaniu konsekwencji decyzji. Na przykład Peters i współpracownicy (Peters, Tompkins, et al., 2019) zbadali rolę poczucia własnej skuteczności 
w zakresie operacji na liczbach (ang. numeric confidence; jednej z podskal w kwestionariuszu subiektywnych zdolności numerycznych) i obiektywnych zdolności numerycznych dla wyników finansowych w dużej $(N=4572)$ i zróżnicowanej próbie Amerykanów. Stwierdzili, że obie kompetencje są dodatnio skorelowane ze sobą oraz wynikami finansowymi (takimi jak posiadane inwestycje, ogłoszenie upadłości, saldo hipoteczne wyższe niż wartość nieruchomości), dobrobytem finansowym (ang. financial well-being; mierzonym takimi pozycjami testowymi jak: „Poradziłbym sobie z poważnym nieoczekiwanym wydatkiem”, „Mam jeszcze pieniądze na koniec miesiąca") i wiedzą finansową (mierzoną takimi pozycjami testowymi jak: „Obligacje są zwykle bardziej ryzykowne niż akcje. Prawda / Fałsz”). Co najważniejsze, Peters i współpracownicy (Peters, Tompkins, et al., 2019) zaobserwowali interakcję między subiektywnymi i obiektywnymi zdolnościami numerycznymi. Osoby z wysokim poziomem obu zdolności osiągnęły najlepsze wyniki finansowe. Jednak osoby, których wyniki w testach zdolności numerycznych były ujemnie skorelowane (tj. osoby z wysokim obiektywnym i niskim subiektywnym poziomem zdolności numerycznych lub niskim obiektywnym i wysokim subiektywnym poziomem zdolności numerycznych), uzyskiwały najgorsze wyniki finansowe. W szczególności osoby, które miały niskie obiektywne, ale wysokie subiektywne zdolności numeryczne podejmowały gorsze decyzje finansowe niż osoby o podobnych obiektywnych zdolnościach numerycznych, którym odpowiadał podobny poziom zdolności subiektywnych (tj. osoby z adekwatnym poczuciem własnej skuteczności w zakresie operacji na liczbach). Analogiczny wzorzec wyników został zaobserwowany także dla decyzji o charakterze medycznym (Peters, Tompkins, et al., 2019) wśród pacjentów ze zdiagnozowanym toczniem rumieniowatym układowym (SLE, systemic lupus erythematosus). Faktyczne nasilenie objawów chorobowych zależało od interakcji między subiektywnymi i obiektywnymi zdolnościami numerycznymi, a układ wyników badania prezentował się podobnie jak w przypadku konsekwencji finansowych.

Problem nadmiernej pewności siebie u osób z wysokimi subiektywnymi zdolnościami numerycznymi podnieśli także niedawno Sobków, Olszewska i Traczyk (Sobkow, Olszewska, et al., 2020). Zauważyli oni, że przy kontroli rozmaitych miar różnic indywidualnych (takich jak statystyczne zdolności numeryczne, szacunkowe zdolności numeryczne, inteligencja płynna oraz refleksyjność poznawcza) subiektywne zdolności numeryczne przewidywały doświadczanie konsekwencji podejmowanych decyzji w codziennym życiu w zaskakujący sposób. Mianowicie osoby, które uzyskały wyższe wyniki w zakresie subiektywnych zdolności numerycznych (tj. oceniały swoje obiektywne zdolności numeryczne jako wyższe i częściej preferowały ich wykorzystywanie), deklarowały, że częściej doświadczały negatywnych konsekwencji swoich decyzji. 


\section{POZNAWCZE, MOTYWACYJNE I AFEKTYWNE MECHANIZMY STOJĄCE}

\section{ZA PROCESEM PODEJMOWANIA DECYZJI PRZEZ OSOBY \\ Z WYSOKIMI ZDOLNOŚCIAMI NUMERYCZNYMI}

Jak zaznaczyliśmy wcześniej, jeden z mechanizmów poznawczych, który stoi za podejmowaniem decyzji przez osoby z wysokim poziomem zdolności numerycznych, może być powiązany z wyrafinowanym przetwarzaniem heurystycznym (Cokely \& Kelley, 2009). Jednakże inne badania wskazują na alternatywne lub dopełniające mechanizmy natury zarówno poznawczej, jak i motywacyjnej (Sobkow, Garrido, et al., 2020). Przykładowo, wyniki badań dość spójnie demonstrują, że osoby z wyższymi zdolnościami numerycznymi są bardziej zmotywowane do przetwarzania problemu decyzyjnego. Mianowicie osoby takie, w porównaniu do osób z niskim poziomem zdolności numerycznych, spędzały więcej czasu na przetwarzaniu problemu decyzyjnego (Ghazal et al., 2014; Petrova, Garcia-Retamero, Catena, \& van der Pligt, 2016), poszukiwały więcej informacji na jego temat, a także przetwarzały te informacje w sposób bardziej spójny i kompleksowy (Ashby, 2017; Traczyk, Lenda, et al., 2018). Wymienione efekty na poziomie motywacyjnym były powiązane z mechanizmami psychofizycznymi, które ujawniały się w bardziej liniowej funkcji użyteczności (Schley \& Peters, 2014) i funkcji wag decyzyjnych (Petrova et al., 2014; Traczyk \& Fulawka, 2016), oraz mechanizmami metapoznawczymi, które przejawiały się w większej pewności dotyczącej trafności podjętej decyzji (Garcia-Retamero, Cokely, \& Hoffrage, 2015).

U podstaw funkcjonowania osób o wysokich zdolnościach numerycznych nie leżą jedynie mechanizmy o charakterze poznawczym czy motywacyjnym, ale również o charakterze emocjonalnym (Zaleskiewicz \& Traczyk, 2020). Na przykład Peters i współpracownicy (2006) zaobserwowali zależność między zdolnościami numerycznymi a afektem (rozumianym jako szybkie i często niekontrolowane podstawowe oceny ewaluatywne, np. że coś jest pozytywne lub negatywne). Zademonstrowali oni, że osoby z wyższym poziomem zdolności numerycznych preferowały udział w grze, w której szansa na wygraną wynosiła 1 na 10, niż w grze, w której szanse wygranej wynosiły 9 na 100. Autorzy thumaczą ten efekt wyższą deklarowaną przez badanych klarownością doznań afektywnych (ang. more clear feelings of goodness or badness). W oparciu o wyniki swoich badań sformułowali wstępną hipotezę, wedle której osoby z wysokim poziomem zdolności numerycznych mogą tworzyć nasyconą afektem umysłową reprezentację problemu decyzyjnego, która pomaga im podejmować dobre decyzje.

Idea ta była rozwijana w kolejnych badaniach. Petrova i współpracownicy (2014) zaobserwowali moderacyjny efekt zdolności numerycznych w relacji między afektem i emocjami a zniekształcaniem prawdopodobieństwa w wagach decyzyjnych. 
Wcześniejsze badania wskazywały, że funkcja wag decyzyjnych (a co za tym idzie - wrażliwość na zmiany prawdopodobieństwa) może być bardziej zakrzywiona w przypadku problemów nacechowanych afektywnie (Rottenstreich \& Hsee, 2001) niż problemów bardziej neutralnych. Oznacza to, że w sytuacji, gdy problem decyzyjny wzbudza silniejsze emocje (np. przy podejmowaniu decyzji o poddaniu się terapii na podstawie informacji o prawdopodobieństwie diagnozy groźnej choroby), decydent będzie mniej wrażliwy na zmiany obiektywnych wartości prawdopodobieństw, niż w przypadku problemów mniej nacechowanych afektywnie (np. przy podejmowaniu decyzji, czy wziąć parasol, na podstawie informacji o prognozowanych opadach deszczu). W badaniu Petrovej i współpracowników (2014) okazało się, że manipulacja emocjami wpłynęła na kształt funkcji wag decyzyjnych: w warunku afektywnym obiektywne prawdopodobieństwa były bardziej zniekształcone niż w warunku kontrolnym. Dodatkowo, osoby z wysokim poziomem zdolności numerycznych w mniejszym stopniu zniekształcały prawdopodobieństwa niż osoby z niższym poziomem zdolności numerycznych. W tym sensie były one bardziej wrażliwe na zmiany prawdopodobieństwa. Co ważne, osoby z wyższym poziomem zdolności numerycznych raportowały bardziej zróżnicowane reakcje emocjonalne w odpowiedzi na zmieniające się wartości prawdopodobieństwa, co w konsekwencji mogło częściowo wytłumaczyć lepsze decyzje tych osób, odzwierciedlone w mniejszym zniekształcaniu prawdopodobieństw w wagach decyzyjnych. W tym sensie osoby z wysokimi zdolnościami numerycznymi skorzystały z istotnej informacji afektywnej podczas podejmowania decyzji. $Z$ drugiej strony, inne badania wykazały, że osoby $z$ wyższym poziomem zdolności numerycznych były mniej podatne na wpływy afektu, który nie jest bezpośrednio powiązany z problemem decyzyjnym i nie niesie żadnej istotnej informacji do podjęcia decyzji (Traczyk \& Fulawka, 2016).

Podsumowując, wyniki przedstawionych badań sugerują, że osoby z wysokim poziomem zdolności numerycznych, w porównaniu do osób z niskim poziomem zdolności numerycznych, mogą adaptacyjnie wykorzystywać informacje afektywne do podejmowania decyzji, co wiąże się z większą deliberacją nad problemem decyzyjnym i mniejszym zniekształceniem wartości numerycznych na poziomie psychofizycznym.

\section{PRAKTYCZNE IMPLIKACJE DLA PODEJMOWANIA DOBRYCH DECYZJI W CODZIENNYCH SYTUACJACH}

W poprzednich rozdziałach argumentowaliśmy, że osoby z wysokim poziomem zdolności numerycznych systematycznie podejmują lepsze decyzje w wielu aspektach życia. Co jednak dzieje się w przypadku osób z niższym poziomem zdolności 
numerycznych? Czy są one skazane na podejmowanie jakościowo gorszych decyzji? Ostatnie badania empiryczne zaznaczają dwie ścieżki wspierania podejmowania decyzji wśród osób o niskim poziomie zdolności numerycznych. Możemy je podzielić na pomoce decyzyjne (głównie pomoce wizualne w postaci wykresów i grafów), które działają w sposób doraźny (w momencie podejmowania decyzji), oraz metody długofalowe, które skupiają się na rozwijaniu umiejętności trafnej oceny ryzyka i umiejętnego podejmowania decyzji.

Ostatnie metaanalizy oraz przeglądy literatury (Garcia-Retamero \& Cokely, 2013, 2017) jasno wskazują, że prawidłowo zaprojektowane pomoce wizualne (rysunek 2) są skutecznym sposobem wspierania osób z niskim poziomem zdolności numerycznych w zrozumieniu informacji numerycznych i ryzyka oraz w podejmowaniu decyzji (Okan, Galesic, \& Garcia-Retamero, 2016; Woller-Carter, Okan, Cokely, \& Garcia-Retamero, 2012). Prezentacja informacji w formie transparentnych i zrozumiałych wykresów czy grafów prowadzi do bardziej wnikliwego przetwarzania informacji (tj. większej deliberacji) oraz tworzenia uogólnionej i nacechowanej afektywnie reprezentacji problemu decyzyjnego. Osoby z niskim poziomem zdolności numerycznych, którym zaprezentowano pomoce wizualne, trafniej oceniały skuteczność terapii oraz lepiej rozumiały ryzyko z nią związane (Galesic \& Garcia-Retamero, 2011; Garcia-Retamero \& Galesic, 2010), trafniej interpretowały wyniki testów diagnostycznych (Garcia-Retamero, Cokely, et al., 2015) oraz były bardziej skłonne poddać się terapii (Okan, Stone, \& Bruin, 2018).

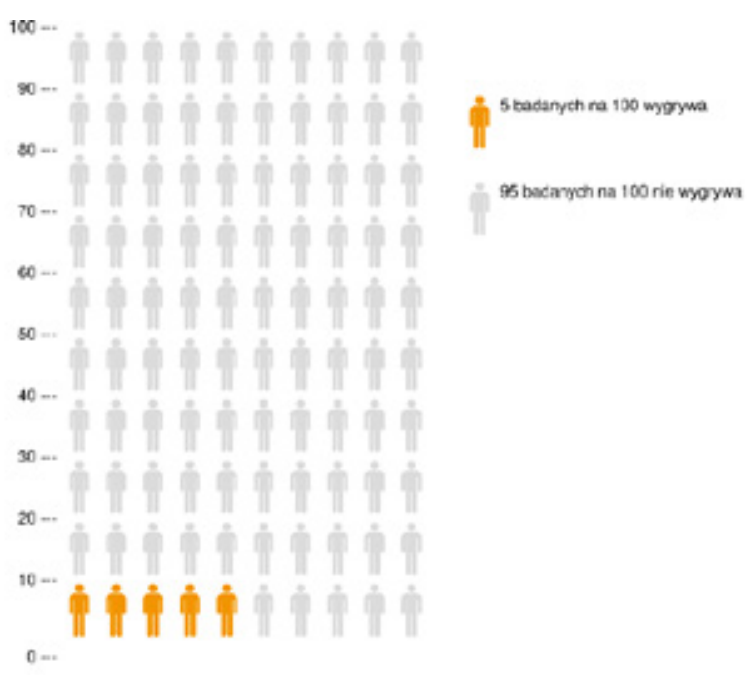

Rysunek 2. Przykład pomocy wizualnej wykorzystanej w badaniach nad percepcją i rozumieniem ryzyka. Wygenerowano za pomocą http://www.iconarray.com/ 
Pomoce wizualne mają jednak dwa poważne ograniczenia. Po pierwsze, specyficzne formy pomocy wizualnych są skuteczne dla specyficznych problemów. Na przykład macierz z ikonami pomaga lepiej zrozumieć wyniki testów diagnostycznych (Garcia-Retamero, Cokely, et al., 2015), ale nie może być wykorzystana do porównania dynamiki i skuteczności różnych terapii. Po drugie, pomoce wizualne są skuteczne wśród osób o niskim poziomie zdolności numerycznych, ale tylko wtedy, kiedy charakteryzują się one średnim lub wysokim poziomem umiejętności czytania i rozumienia wykresów oraz grafów (Galesic \& Garcia-Retamero, 2011; Garcia-Retamero \& Galesic, 2010; Okan et al., 2016; Okan, Garcia-Retamero, Cokely, \& Maldonado, 2012). W związku z tym konieczne jest rozwijanie nowych metod komunikowania informacji numerycznych, które będą działały niezależnie od problemu oraz poziomu umiejętności czytania i rozumienia wykresów.

Przewidywania modeli teoretycznych oraz wyniki badań wskazują, że ludzie posiadają zdolność do automatycznego kodowania i przetwarzania frekwencji (Hasher \& Zacks, 1984; Zacks \& Hasher, 2002) oraz utajonego uczenia się skomplikowanych wzorców w przypadku sztucznych gramatyk (Reber, 1993; Sobkow, Traczyk, Kaufman, \& Nosal, 2018) czy nabywania kowariancji (Catena, Maldonado, \& Cándido, 1998). Na tej podstawie wielu badaczy dostarczyło empirycznych dowodów świadczących o tym, że komunikowanie informacji w formacie doświadczeniowym, który polega na aktywnej obserwacji dynamicznie i sekwencyjnie pojawiających się bodźców sygnalizujących częstość ich występowania w danym zbiorze (np. prezentacji serii szybko zmieniających się 7 bodźców docelowych „X” oraz 13 dystraktorów „•, które sekwencyjnie i losowo pojawiają się na ekranie) w porównaniu z pasywną obserwacją ich statycznej formy (np. informacji, że jest 7 bodźców „X” oraz 13 „”), jest pomocne w trafnej ocenie ryzyka i lepszym jego zrozumieniu (Armstrong \& Spaniol, 2017; Tyszka \& Sawicki, 2011; Wegier \& Shaffer, 2017). W szczególności format doświadczeniowy może przynieść wymierne korzyści dla osób z niskim poziomem zdolności numerycznych. Na poparcie tej hipotezy Traczyk i współpracownicy (Traczyk, Sobkow, Matukiewicz, Petrova, \& Garcia-Retamero, 2019) wykazali w badaniu eksperymentalnym, że w przypadku osób o wysokim poziomie zdolności numerycznych format prezentacji informacji o prawdopodobieństwie (opisowy vs doświadczeniowy) nie miał znaczenia dla oszacowania prawdopodobieństwa ani dla średniego odchylenia od prawidłowej odpowiedzi. Jednakże zastosowanie formatu doświadczeniowego pomogło osobom o niskim poziomie zdolności numerycznych w dokonywaniu lepszych oszacowań, które były zoperacjonalizowane jako większa wrażliwość na zmiany prawdopodobieństwa oraz mniejsze średnie odchylenie od prawidłowej odpowiedzi. Dzięki formatowi doświadczeniowemu wzorzec wyników osób z niskim poziomem zdolności numerycznych nie różnił się od wzorca wyników wśród osób z wyższym poziomem zdolności numerycznych. 
Mimo wielu empirycznych dowodów wskazujących, że pomoce wizualne oraz doświadczeniowy format prezentacji informacji numerycznych wspierają ocenę i zrozumienie ryzyka oraz podejmowanie dobrych decyzji, to wciąż metody te są wykorzystywane w sposób doraźny. W tym sensie ich efekty są natychmiastowe, ale raczej nie wpływają na trwałą zmianę w sposobie przetwarzania informacji w innych problemach.

Zdolności numeryczne zdają się być względnie stabilną cechą, jednakże istnieją pierwsze wyniki badań, które wskazują na możliwość zastosowania skutecznych interwencji wpływających zarówno na poziom samych zdolności numerycznych, jak i na powiązane z nimi podejmowanie lepszych decyzji (Peters, 2017). Interwencje te mogą przybierać formę treningów poznawczych lub działań edukacyjnych.

Pierwsze wyniki badań nad efektywnością treningów poznawczych (Jaeggi, Buschkuehl, Jonides, \& Perrig, 2008; Jaeggi et al., 2010) niosły za sobą duże nadzieje i oczekiwania. Pokazywały one, że nawet relatywnie krótki (kilkutygodniowy) trening pamięci roboczej może znacząco zwiększyć poziom inteligencji płynnej. Niestety, późniejsze badania oraz metaanalizy (Au et al., 2015; Melby-Lervåg \& Hulme, 2013) wykazały, że co prawda trening pamięci roboczej wpływał na wyniki uzyskiwane w testach inteligencji, ale efekt ten był słabszy niż w pierwszych badaniach, a nawet zanikał po kilku miesiącach od zakończenia treningu. Efektywność komercyjnych treningów poznawczych jest również co najmniej wątpliwa (Kable et al., 2017; Simons et al., 2016), a wiele z badań dotyczących skuteczności treningów poznawczych było obarczonych poważnymi błędami metodologicznymi (takimi jak brak losowego doboru uczestników do grup eksperymentalnych czy brak adekwatnej grupy kontrolnej).

Jedną z nielicznych interwencji, która z jednej strony wykazała potencjał oddziaływania na zdolności numeryczne i podejmowanie decyzji, a z drugiej - została przetestowana w badaniach z zachowaniem rygoru metodologicznego (Nęcka, 2018; Simons et al., 2016), jest trening mentalnej osi liczbowej opracowany przez Sobków i współpracowników (2019). Trening ten opierał się na idei szacunkowych zdolności numerycznych i został zainspirowany grą dla dzieci z dyskalkulią - Rescue Calcularis (Kucian et al., 2011).

W badaniu Sobków i współpracowników (2019) osoby badane (młodzi dorośli) zostały losowo przydzielone do dwóch warunków badawczych: treningu mentalnej osi liczbowej lub aktywnego warunku kontrolnego. W pierwszej grupie osoby były proszone o oszacowanie wyniku działania arytmetycznego (np. $23+2)$ i zaznaczenie wyniku na suwaku o określonych wartościach krańcowych (zob. pomiar szacunkowych zdolności numerycznych w tabeli 1). W drugiej grupie osoby badane dokonywały tylko oszacowań prawidłowej odpowiedzi bez konieczności zaznaczania ich na suwaku. Po zakończeniu treningu (9 sesji o różnym stopniu trudności, każda po 20-30 
minut) osoby z grupy eksperymentalnej (w porównaniu z osobami z grupy kontrolnej) precyzyjniej umieszczały wartości liczbowe na suwaku, co świadczy o skuteczności treningu w zakresie poprawy szacunkowych zdolności numerycznych. Dodatkowo został także zaobserwowany transfer na inne funkcje poznawcze. Na przykład w zadaniu odzwierciedlającym codzienne podejmowanie decyzji osoby z grupy treningu mentalnej osi liczbowej precyzyjniej estymowały kwotę, jaką należy zapłacić za zakupy, na podstawie krótkiego zapoznania się z paragonem zawierającym listę produktów. Okazało się również, że zarówno trening mentalnej osi liczbowej, jak i trening arytmetyczny w aktywnej grupie kontrolnej prowadzily do wzrostu poziomu subiektywnych zdolności numerycznych oraz wzrostu liczby decyzji bliższych przewidywaniom modelu normatywnego (w porównaniu z poziomem sprzed treningu). Warto jednak zauważyć, że pomimo interesujących i obiecujących wyników tego badania, jest to rezultat pojedynczego eksperymentu i potrzeba dalszych badań dotyczących zarówno zakresu transferu, jak i stabilności efektów treningu w czasie.

Treningi poznawcze są zazwyczaj relatywnie krótkotrwałe (Nęcka, 2018), ich oddziaływanie może być więc bardziej subtelne niż formalnej edukacji, która zwykle trwa wiele miesięcy lub lat. W wyniku niedawnej metaanalizy (Ritchie \& Tucker-Drob, 2018) oszacowano, że każdy rok edukacji powodowa $1^{4}$ podwyższenie inteligencji od 1 do 5 pkt. IQ. Efekt edukacji obecny był zarówno w przypadku, gdy brano pod uwagę zadania mierzące inteligencję płynną, jak i skrystalizowaną. O ile w przypadku inteligencji skrystalizowanej, która z definicji rozwija się „jako wynik doświadczenia i uczenia się" (Strelau, 2014, p. 84), nie jest to zaskakujące, to w przypadku inteligencji płynnej, która „uwarunkowana jest właściwością fizjologiczną struktur nerwowych w mózgu i zależy w decydującej mierze od czynnika genetycznego" (Strelau, 2014, p. 84), ten wynik jest nieoczywisty. Ritchie i Tucker-Drob (2018) zaznaczają także, że wpływ edukacji na inteligencję może nie być liniowy - wraz z czasem trwania edukacji jej efekt może się zmniejszać, aż do pojawienia się plateau. Niemniej jednak metaanaliza ta wykazała, że edukacja pełni zasadniczą rolę w rozwoju zdolności poznawczych.

W celu sprawdzenia, czy edukacja wpływa jedynie na wyniki uzyskiwane w testach inteligencji, czy też przekłada się ona na realne wybory w codziennym życiu, Estrada-Mejia i współpracownicy (2020) przeprowadzili badanie na specyficznej populacji - mianowicie na członkach plemienia Indian Keczua (Quechua), którzy żyją w Peru. Jest to społeczność bardzo jednorodna pod względem zawodu (rolnicy), wykształcenia rodziców czy dostępu do usług finansowych. Co jednak szczególnie istotne, wśród Indian Keczua występuje większe niż w krajach wysoko rozwiniętych zróżnicowanie pod względem liczby lat edukacji poszczególnych członków

4 Do tej metaanalizy zostały włączone jedynie badania, których schemat upoważniał do wyciągania wniosków o związkach przyczynowo-skutkowych. 
społeczności (w tym badaniu liczba lat edukacji wahała się od 0 do 16). Wyniki tego badania wykazały, że liczba lat edukacji wiązała się zarówno z miarami zdolności poznawczych (inteligencji płynnej, inteligencji skrystalizowanej, zdolności numerycznych), jak i z posiadanym majątkiem. Co więcej, tylko zdolności numeryczne, a nie inteligencja (płynna czy skrystalizowana), pełniły funkcję mediatora między latami edukacji a posiadanym majątkiem (Rysunek 3). Choć badanie miało korelacyjny charakter i nie pozwala na wyciąganie jednoznacznych wniosków o charakterze przyczynowo-skutkowym, to sugeruje, że edukacja może mieć wpływ na poprawę zdolności numerycznych, co również może przekładać się na podejmowanie lepszych decyzji w codziennym życiu.

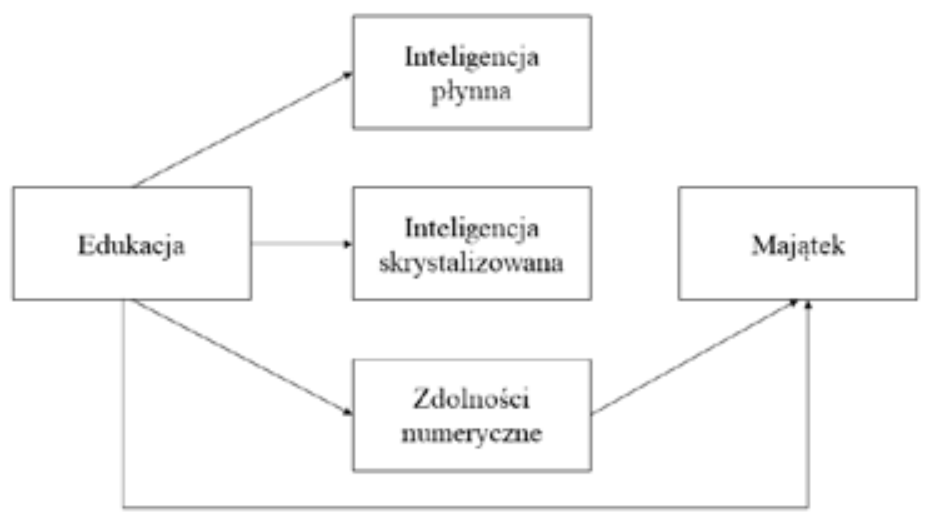

Rysunek 3. Mediacyjny efekt zdolności numerycznych w relacji miedzy latami edukacji a zgromadzonym majątkiem (na podstawie Estrada-Mejia et al., 2020; Sobkow, Garrido, et al., 2020)

Okazuje się jednak, że nie tylko liczba lat edukacji, ale również jej jakość (czego i w jaki sposób się uczymy) może mieć kluczowe znaczenie dla rozwoju zdolności poznawczych. Na przykład: Peters i współpracownicy (2017) dokonali weryfikacji interwencji, która miała na celu zwiększenie poziomu zdolności numerycznych, poprawę jakości podejmowanych decyzji oraz polepszenie wyników w uniwersyteckich kursach o charakterze matematyczno-techniczno-przyrodniczym. Studenci uczęszczający na zajęcia ze statystyki zostali losowo przydzieleni do jednego z dwóch warunków badawczych. W warunku eksperymentalnym studenci rangowali różne wartości (takie jak religia, wiedza itp.) pod względem ich osobistego znaczenia i argumentowali, dlaczego dana wartość została przez nich wybrana za najważniejszą. Natomiast w warunku kontrolnym studenci argumentowali, dlaczego najmniej istotna dla nich wartość może być ważna dla innych osób. Autorzy badania postawili hipotezę, że 
taka interwencja podwyższy poziom obiektywnych zdolności numerycznych, ponieważ afirmacja wartości może zmienić postrzeganie zajęć przez studentów i sprawi, że wyniosą z nich więcej korzyści. Wyniki badania pokazały, że w warunku kontrolnym poziom obiektywnych zdolności numerycznych nie uległ zmianie. Co więcej, poziom subiektywnych zdolności numerycznych obniżył się. Odmienne rezultaty uzyskano w warunku eksperymentalnym. Studenci, którzy afirmowali swoje wartości na początku kursu, uzyskali później wyższe wyniki w teście obiektywnych zdolności numerycznych, a ich subiektywne zdolności numeryczne pozostały na stałym poziomie. Badacze zaobserwowali także, że osoby badane przydzielone do warunku eksperymentalnego podejmowały lepsze decyzje, uzyskiwały lepsze oceny w ramach zajęć akademickich i były bardziej skłonne wybierać kursy z obszaru nauk ścisłych. Autorzy tego badania sugerują, że efekty te mogą być związane ze wzrostem poziomu obiektywnych i subiektywnych zdolności numerycznych.

\section{Podsumowanie}

Liczne modele teoretyczne (np. Brandstätter et al., 2006; Busemeyer \& Townsend, 1993; Loomes \& Sugden, 1982; Lopes, 1987; Quiggin, 1982; Tversky \& Kahneman, 1992) aspirujące do opisania i wyjaśnienia procesu podejmowania decyzji rzadko uwzględniały rolę różnic indywidualnych w zakresie zdolności poznawczych, skupiając się głównie na modelowaniu wyborów w oparciu o numeryczne charakterystyki problemów decyzyjnych, takie jak wartości finansowe zysków lub strat i przypisane do nich poziomy prawdopodobieństwa. Pomimo nieocenionego wkładu tych modeli dla zrozumienia czynników kierujących podejmowaniem decyzji w warunkach ryzyka i niepewności, ich wartość deskryptywna może być znacznie wzbogacona poprzez uwzględnienie zmiennych indywidualnych związanych ze zdolnościami numerycznymi jako moderatorów badanych zależności. Biorąc pod uwagę wyniki badań empirycznych, które sugerują, że osoby z niskim poziomem zdolności numerycznych (w porównaniu do osób z wysokim poziomem zdolności numerycznych) mają trudności z przetwarzaniem informacji numerycznych (np. prawdopodobieństw), uwzględnienie różnic w zakresie tych zdolności może rzucić nowe światło (por. Broniatowski \& Reyna, 2018; Peters \& Levin, 2008) na zrozumienie klasycznych efektów, takich jak paradoks Allaisa (1953) czy efekt sformułowania (Tversky \& Kahneman, 1981). Te nowe odkrycia z kolei mogą przyczynić się do rozwoju efektywnych metod wsparcia procesu decyzyjnego wśród osób z niskim poziomem zdolności numerycznych. 


\section{BiBLIOGRAFIA}

Allais, M. (1953). L' Extension des Theories de l'Equilibre Economique General et du Rendement Social au Cas du Risque. Econometrica, 21(2), 269-290. Retrieved from https://www.jstor.org/ stable/1905539

Allan, J.N. (2018). Numeracy vs. Intelligence: A model of the relationship between cognitive abilities and decision making. University of Oklahoma. Retrieved from https://shareok.org/handle/11244/299906

Armstrong, B., \& Spaniol, J. (2017). Experienced Probabilities Increase Understanding of Diagnostic Test Results in Younger and Older Adults. Medical Decision Making, 37(6), 670-679. https:// doi.org/10.1177/0272989X17691954

Ashby, N.J.S. (2017). Numeracy predicts preference consistency: Deliberative search heuristics increase choice consistency for choices from description and experience. Judgment and Decision Making, 12(2), 128-139.

Au, J., Sheehan, E., Tsai, N., Duncan, G.J., Buschkuehl, M., \& Jaeggi, S.M. (2015). Improving fluid intelligence with training on working memory: a meta-analysis. Psychonomic Bulletin and Review, 22(2), 366-377. https://doi.org/10.3758/s13423-014-0699-x

Baron, J. (2008). Thinking and deciding (4th ed.). Cambridge, UK: Cambridge University Press.

Brandstätter, E., Gigerenzer, G., \& Hertwig, R. (2006). The priority heuristic: making choices without trade-offs. Psychological Review, 113(2), 409-432. https://doi.org/10.1037/0033-295X.113.2.409

Broniatowski, D.A., \& Reyna, V. F. (2018). A formal model of fuzzy-trace theory: Variations on framing effects and the Allais Paradox. Decision, 5(4), 205-252. https://doi.org/10.1037/dec0000083

Busemeyer, J., \& Townsend, J. (1993). Decision field theory: a dynamic-cognitive approach to decision making in an uncertain environment. Psychological Review, 100(3), 432-459.

Campbell, J.I.D. (Ed.). (2005). Handbook of Mathematical Cognition. New York, NY: Taylor \& Francis Group.

Carroll, J.B. (1993). Human cognitive abilities. Cambridge: Cambridge University Press.

Catena, A., Maldonado, A., \& Cándido, A. (1998). The effect of frequency of judgement and the type of trials on covariation learning. Journal of Experimental Psychology: Human Perception and Performance, 24(2), 481-495. https://doi.org/10.1037/0096-1523.24.2.481

Cokely, E.T., Feltz, A., Ghazal, S., Allan, J.N., Petrova, D.G., \& Garcia-Retamero, R. (2018). Decision Making Skill: From Intelligence to Numeracy and Expertise. In K.A. Ericsson, R.R. Hoffman, A. Kozbelt, \& A.M. Williams (Eds.), Cambridge Handbook of Expertise and Expert Performance (2nd ed., pp. 476-505). New York, NY: Cambridge University Press.

Cokely, E.T., Galesic, M., Schult, E., \& Garcia-Retamero, R. (2012). Measuring Risk Literacy: The Berlin Numeracy Test. Judgment and Decision Making, 7(1), 25-47.

Cokely, E.T., \& Kelley, C.M. (2009). Cognitive abilities and superior decision making under risk: A protocol analysis and process model evaluation. Judgment and Decision Making, 4(1), 20-33.

Dehaene, S. (1997). The number sense: how the mind creates mathematics. Oxford, England: Oxford University Press. 
Dehaene, S. (2003). The neural basis of the Weber-Fechner law: a logarithmic mental number line. Trends in Cognitive Sciences, 7(4), 145-147. https://doi.org/10.1016/S1364-6613(03)00055-X

Dolan, J.G., Cherkasky, O.A., Li, Q., Chin, N., \& Veazie, P.J. (2016). Should Health Numeracy Be Assessed Objectively or Subjectively? Medical Decision Making, 36(7), 868-875. https://doi.org/10.1177/0272989X15584332

Estrada-Mejia, C., de Vries, M., \& Zeelenberg, M. (2016). Numeracy and wealth. Journal of Economic Psychology, 54(1), 53-63. https://doi.org/10.1016/j.joep.2016.02.011

Estrada-Mejia, C., Peters, E., Dieckmann, N.F., Zeelenberg, M., De Vries, M., \& Baker, D. P. (2020). Schooling, numeracy, and wealth accumulation: A study involving an agrarian population. Journal of Consumer Affairs. https://doi.org/10.1111/joca.12294

Fagerlin, A., Zikmund-Fisher, B.J., Ubel, P.A., Jankovic, A., Derry, H.A., \& Smith, D.M. (2007). Measuring numeracy without a math test: Development of the subjective numeracy scale. Medical Decision Making, 27(5), 672-680. https://doi.org/10.1177/0272989X07304449

Galesic, M., \& Garcia-Retamero, R. (2011). Graph Literacy A Cross-Cultural Comparison. Medical Decision Making, 31(3), 444-457. https://doi.org/10.1177/0272989X10373805

Garcia-Retamero, R., Andrade, A., Sharit, J., \& Ruiz, J.G. (2015). Is patients' numeracy related to physical and mental health? Medical Decision Making, 35(4), 501-511. https://doi.org/10.1177/0272989X15578126

Garcia-Retamero, R., \& Cokely, E.T. (2013). Communicating Health Risks With Visual Aids. Current Directions in Psychological Science, 22(5), 392-399. https://doi.org/10.1177/0963721413491570

Garcia-Retamero, R., \& Cokely, E.T. (2017). Designing Visual Aids That Promote Risk Literacy: A Systematic Review of Health Research and Evidence-Based Design Heuristics. Human Factors: The Journal of the Human Factors and Ergonomics Society, 59(4), 582-627. https://doi. org/10.1177/0018720817690634

Garcia-Retamero, R., Cokely, E.T., \& Hoffrage, U. (2015). Visual aids improve diagnostic inferences and metacognitive judgment calibration. Frontiers in Psychology, 6(932), 1-12. https://doi. org/10.3389/fpsyg.2015.00932

Garcia-Retamero, R., \& Galesic, M. (2010). Who proficts from visual aids: Overcoming challenges in people's understanding of risks. Social Science and Medicine, 70(7), 1019-1025. https://doi. org/10.1016/j.socscimed.2009.11.031

Garcia-Retamero, R., Sobkow, A., Petrova, D. G., Garrido, D., \& Traczyk, J. (2019). Numeracy and Risk Literacy: What Have We Learned so Far? Spanish Journal of Psychology, e10, 1-11. https:// doi.org/10.1017/sjp.2019.16

Ghazal, S., Cokely, E.T., \& Garcia-Retamero, R. (2014). Predicting biases in very highly educated samples: Numeracy and metacognition. Judgment and Decision Making, 9(1), 15-34.

Hasher, L., \& Zacks, R.T. (1984). Automatic processing of fundamental information: The case of frequency of occurrence. American Psychologist, 39(12), 1372-1388. https://doi.org/10.1037/0003$-066 X .39 .12 .1372$

Hogarth, R.M. (2015). What's a "Good” Decision? Issues in Assessing Procedural and Ecological Quality. In G. Keren \& G. Wu (Eds.), The Wiley Blackwell Handbook of Judgement and Decision Making (pp. 952-972). John Wiley \& Sons, Ltd. 
Izard, V., \& Dehaene, S. (2008). Calibrating the mental number line. Cognition, 106(3), 1221-1247. https://doi.org/10.1016/j.cognition.2007.06.004

Jaeggi, S.M., Buschkuehl, M., Jonides, J., \& Perrig, W.J. (2008). Improving fluid intelligence with training on working memory. Proceedings of the National Academy of Sciences of the United States of America, 105(19), 6829-6833. https://doi.org/10.1073/pnas.0801268105

Jaeggi, S.M., Studer-Luethi, B., Buschkuehl, M., Su, Y.F., Jonides, J., \& Perrig, W.J. (2010). The relationship between n-back performance and matrix reasoning - implications for training and transfer. Intelligence, 38(6), 625-635. https://doi.org/10.1016/j.intell.2010.09.001

Jasper, J.D., Bhattacharya, C., \& Corser, R. (2017). Numeracy Predicts More Effortful and Elaborative Search Strategies in a Complex Risky Choice Context: A Process-Tracing Approach. Journal of Behavioral Decision Making, 30(2), 224-235. https://doi.org/10.1002/bdm.1934

Jasper, J.D., Bhattacharya, C., Levin, I.P., Jones, L., \& Bossard, E. (2013). Numeracy as a Predictor of Adaptive Risky Decision Making. Journal of Behavioral Decision Making, 26(2), 164-173. https://doi.org/10.1002/bdm.1748

Kable, J.W., Caulfield, M.K., Falcone, M., McConnell, M., Bernardo, L., Parthasarathi, T., ... Lerman, C. (2017). No Effect of Commercial Cognitive Training on Brain Activity, Choice Behavior, or Cognitive Performance. The Journal of Neuroscience, 37(31), 7390-7402. https://doi. org/10.1523/JNEUROSCI.2832-16.2017

Kahneman, D., \& Tversky, A. (1979). Prospect Theory: An Analysis of Decision under Risk. Econometrica, 47(2), 263-292.

Kucian, K., Grond, U., Rotzer, S., Henzi, B., Schönmann, C., Plangger, F., ... von Aster, M. (2011). Mental number line training in children with developmental dyscalculia. NeuroImage, 57(3), 782-795. https://doi.org/10.1016/j.neuroimage.2011.01.070

Låg, T., Bauger, L., Lindberg, M., \& Friborg, O. (2014). The Role of Numeracy and Intelligence in Health-Risk Estimation and Medical Data Interpretation. Journal of Behavioral Decision Making, 27(2), 95-108. https://doi.org/10.1002/bdm.1788

Leibovich, T., Katzin, N., Harel, M., \& Henik, A. (2017). From "sense of number" to "sense of magnitude": The role of continuous magnitudes in numerical cognition. Behavioral and Brain Sciences, 40, e164. https://doi.org/10.1017/S0140525X16000960

Liberali, J.M., Reyna, V.F., Furlan, S., Stein, L.M., \& Pardo, S. T. (2012). Individual Differences in Numeracy and Cognitive Reflection, with Implications for Biases and Fallacies in Probability Judgment. Journal of Behavioral Decision Making, 25(4), 361-381. https://doi.org/10.1002/ bdm.752

Lipkus, I.M., Samsa, G., \& Rimer, B.K. (2001). General performance on a numeracy scale among highly educated samples. Medical Decision Making, 21(1), 37-44. https://doi.org/10.1177/0272989X0102100105

Loomes, G., \& Sugden, R. (1982). Regret Theory: An Alternative Theory of Rational Choice Under Uncertainty. The Economic Journal, 92(368), 805-824. https://doi.org/10.2307/2232669

Lopes, L.L. (1987). Between hope and fear: The psychology of risk. Advances in Experimental Social Psychology, 20, 255-295. https://doi.org/10.1016/S0065-2601(08)60416-5

Melby-Lervåg, M., \& Hulme, C. (2013). Is working memory training effective? A meta-analytic review. Developmental Psychology, 49(2), 270-291. https://doi.org/10.1037/a0028228 
Miron-Shatz, T., Hanoch, Y., Doniger, G.M., Omer, Z.B., \& Ozanne, E.M. (2014). Subjective but not objective numeracy influences willingness to pay for BRCA1 / 2 genetic testing. Judgment and Decision Making, 9(2), 152-158.

Nęcka, E. (2018). Trening poznawczy [The cognitive training]. Warszawa: PWN.

Okan, Y., Galesic, M., \& Garcia-Retamero, R. (2016). How People with Low and High Graph Literacy Process Health Graphs: Evidence from Eye-tracking. Journal of Behavioral Decision Making, 29(2-3), 271-294. https://doi.org/10.1002/bdm.1891

Okan, Y., Garcia-Retamero, R., Cokely, E.T., \& Maldonado, A. (2012). Individual Differences in Graph Literacy: Overcoming Denominator Neglect in Risk Comprehension. Journal of Behavioral Decision Making, 25(4), 390-401. https://doi.org/10.1002/bdm.751

Okan, Y., Stone, E.R., \& Bruin, B. de B. (2018). Designing Graphs that Promote Both Risk Understanding and Behavior Change. Risk Analysis, 38(5), 929-946. https://doi.org/10.1111/risa.12895

Park, I., \& Cho, S. (2018). The influence of number line estimation precision and numeracy on risky financial decision making. International Journal of Psychology. https://doi.org/10.1002/ ijop. 12475

Payne, J. W., Bettman, J.R.J.R., \& Johnson, E.J.E. (1988). Adaptive strategy selection in decision making. Journal of Experimental Psychology: Learning, Memory, and Cognition, 14(3), 534. Retrieved from http://psycnet.apa.org/journals/xlm/14/3/534/

Payne, J. W., Bettman, J.R., \& Johnson, E.J. (1993). The Adaptive Decision Maker. Cambridge: Cambridge University Press.

Peters, E. (2017). Educating good decisions. Behavioural Public Policy, 1(02), 162-176. https://doi. org/10.1017/bpp.2016.15

Peters, E., \& Bjälkebring, P. (2015). Multiple numeric competencies: When a number is not just a number. Journal of Personality and Social Psychology, 108(5), 802-822. https://doi.org/10.1037/ pspp0000019

Peters, E., Fennema, M.G., \& Tiede, K.E. (2019). The loss-bet paradox: Actuaries, accountants, and other numerate people rate numerically inferior gambles as superior. Journal of Behavioral Decision Making, 32(1), 15-29. https://doi.org/10.1002/bdm.2085

Peters, E., \& Levin, I.P. (2008). Dissecting the risky-choice framing effect: Numeracy as an individual-difference factor in weighting risky and riskless options. Judgment and Decision Making, 3(6), 435-448.

Peters, E., Shoots-Reinhard, B., Tompkins, M.K., Schley, D., Meilleur, L., Sinayev, A., ... Crocker, J. (2017). Improving numeracy through values affirmation enhances decision and STEM outcomes. PLOS ONE, 12(7), e0180674. https://doi.org/10.1371/journal.pone.0180674

Peters, E., Tompkins, M.K., Knoll, M.A.Z., Ardoin, S.P., Shoots-Reinhard, B., \& Meara, A. S. (2019). Despite high objective numeracy, lower numeric confidence relates to worse financial and medical outcomes. Proceedings of the National Academy of Sciences, 116(39), 19386-19391. https:// doi.org/10.1073/pnas.1903126116

Peters, E., Västfjäll, D., Slovic, P., Mertz, C.K., Mazzocco, K., \& Dickert, S. (2006). Numeracy and decision making. Psychological Science, 17(5), 407-413. https://doi.org/10.1111/j.1467$-9280.2006 .01720 . x$ 
Petrova, D.G., Garcia-Retamero, R., Catena, A., Cokely, E., Heredia Carrasco, A., Arrebola Moreno, A., \& Ramírez Hernández, J.A. (2017). Numeracy Predicts Risk of Pre-Hospital Decision Delay: a Retrospective Study of Acute Coronary Syndrome Survival. Annals of Behavioral Medicine, 51(2), 292-306. https://doi.org/10.1007/s12160-016-9853-1

Petrova, D.G., Garcia-Retamero, R., Catena, A., \& van der Pligt, J. (2016). To screen or not to screen: What factors influence complex screening decisions? Journal of Experimental Psychology: Applied, 22(2), 247-260. https://doi.org/10.1037/xap0000086

Petrova, D.G., Kostopoulou, O., Delaney, B. C., Cokely, E.T., \& Garcia-Retamero, R. (2018). Strengths and Gaps in Physicians' Risk Communication: A Scenario Study of the Influence of Numeracy on Cancer Screening Communication. Medical Decision Making, 38(3), 355-365. https://doi. org/10.1177/0272989X17729359

Petrova, D.G., Traczyk, J., \& Garcia-Retamero, R. (2019). What shapes the probability weighting function? Influence of affect, numeric competencies, and information formats. Journal of Behavioral Decision Making, 32(2), 124-139. https://doi.org/10.1002/bdm.2100

Petrova, D.G., van der Pligt, J., \& Garcia-Retamero, R. (2014). Feeling the Numbers: On the Interplay Between Risk, Affect, and Numeracy. Journal of Behavioral Decision Making, 27(3), 191199. https://doi.org/10.1002/bdm.1803

Quiggin, J. (1982). A theory of anticipated utility. Journal of Economic Behavior \& Organization, 3(4), 323-343. https://doi.org/10.1016/0167-2681(82)90008-7

Reber, A.S. (1993). Implicit Learning and Tacit Knowledge. New York: Oxford University Press.

Reyna, V.F., \& Brainerd, C.J. (1995). Fuzzy-trace theory: An interim synthesis. Learning and Individual Differences, 7(1), 1-75. https://doi.org/10.1016/1041-6080(95)90031-4

Reyna, V.F., \& Brainerd, C.J. (2008). Numeracy, ratio bias, and denominator neglect in judgments of risk and probability. Learning and Individual Differences, 18(1), 89-107. https://doi.org/10.1016/j. lindif.2007.03.011

Reyna, V.F., \& Brainerd, C.J. (2011). Dual Processes in Decision Making and Developmental Neuroscience: A Fuzzy-Trace Model. Developmental Review, 31(2-3), 180-206. https://doi.org/10.1016/j. dr.2011.07.004

Reyna, V., \& Brust-Renck, P. (2014). A review of theories of numeracy: Psychological mechanisms and implications for medical decision making. In B. Anderson \& J. Schulkin (Eds.), Numerical Reasoning in Judgments and Decision Making about Health (pp. 215-251). Cambridge: Cambridge University Press. doi:10.1017/CBO9781139644358.011

Reyna, V.F., \& Brust-Renck, P.G. (2020). How representations of number and numeracy predict decision paradoxes: A fuzzy-trace theory approach. Journal of Behavioral Decision Making, (February), 1-23. https://doi.org/10.1002/bdm.2179

Reyna, V.F., Estrada, S.M., DeMarinis, J.A., Myers, R.M., Stanisz, J.M., \& Mills, B.A. (2011). Neurobiological and memory models of risky decision making in adolescents versus young adults. Journal of Experimental Psychology: Learning, Memory, and Cognition, 37(5), 1125-1142. https:// doi.org/10.1037/a0023943

Reyna, V.F., Nelson, W.L., Han, P.K., \& Dieckmann, N.F. (2009). How numeracy influences risk comprehension and medical decision making. Psychological Bulletin, 135(6), 943-973. https:// doi.org/10.1037/a0017327 
Reyna, V.F., Rahimi-Golkhandan, S., Garavito, D.M.N., \& Helm, R.K. (2018). The fuzzy-trace process model. In W. De Neys (Ed.), Dual Process Theory 2.0 (pp. 82-99). New York, NY: Routledge.

Reynvoet, B., \& Sasanguie, D. (2016). The Symbol Grounding Problem Revisited: A Thorough Evaluation of the ANS Mapping Account and the Proposal of an Alternative Account Based on Symbol-Symbol Associations. Frontiers in Psychology, 07. https://doi.org/10.3389/fpsyg.2016.01581

Ritchie, S.J., \& Tucker-Drob, E. M. (2018). How Much Does Education Improve Intelligence? A Meta-Analysis. Psychological Science, 29(8), 1358-1369. https://doi.org/10.1177/0956797618774253

Rottenstreich, Y., \& Hsee, C.K. (2001). Money, kisses, and electric shocks: on the affective psychology of risk. Psychological Science, 12(3), 185-190. https://doi.org/10.1111/1467-9280.00334

Schley, D.R., \& Peters, E. (2014). Assessing "Economic Value": Symbolic-Number Mappings Predict Risky and Riskless Valuations. Psychological Science, 25(3), 753-761. https://doi. org/10.1177/0956797613515485

Schwartz, L.M., Woloshin, S., Black, W.C., \& Welch, H.G. (1997). The role of numeracy in understanding the benefit of screening mammography. Annals of Internal Medicine, 127(11), 966-972. https://doi.org/10.7326/0003-4819-127-11-199712010-00003

Simon, H.A. (1990). Invariants of human behavior. Annual Review of Psychology, 41(1), 1-20. https://doi.org/10.1146/annurev.biochem.64.1.721

Simons, D.J., Boot, W. R., Charness, N., Gathercole, S.E., Chabris, C.F., Hambrick, D.Z., \& Stine-Morrow, E.A.L.L. (2016). Do "Brain-Training" Programs Work? Psychological Science in the Public Interest, 17(3), 103-186. https://doi.org/10.1177/1529100616661983

Sobkow, A., Fulawka, K., Tomczak, P., Zjawiony, P., \& Traczyk, J. (2019). Does mental number line training work? The effects of cognitive training on real-life mathematics, numeracy, and decision making. Journal of Experimental Psychology: Applied, 25(3), 372-385. https://doi.org/10.1037/ xap0000207

Sobkow, A., Garrido, D., \& Garcia-Retamero, R. (2020). Cognitive Abilities and Financial Decision Making. In T. Zaleskiewicz \& J. Traczyk (Eds.), Psychological Perspectives on Financial Decision Making, (pp. 71-87). New York: Springer.

Sobkow, A., Olszewska, A., \& Traczyk, J. (2020). Multiple numeric competencies predict decision outcomes beyond fluid intelligence and cognitive reflection. Intelligence, 80, 101452. https://doi. org/10.1016/j.intell.2020.101452

Sobkow, A., Traczyk, J., Kaufman, S. B., \& Nosal, C. (2018). The structure of intuitive abilities and their relationships with intelligence and Openness to Experience. Intelligence, 67, 1-10. https:// doi.org/10.1016/j.intell.2017.12.001

Strelau, J. (2014). Różnice indywidualne. Historia-determinanty-zastosowanie. Scholar.

Traczyk, J., \& Fulawka, K. (2016). Numeracy moderates the influence of task-irrelevant affect on probability weighting. Cognition, 151, 37-41. https://doi.org/10.1016/j.cognition.2016.03.002

Traczyk, J., Lenda, D., Serek, J., Fulawka, K., Tomczak, P., Strizyk, K., ... Sobkow, A. (2018). Does fear increase search effort in more numerate people? An experimental study investigating information acquisition in a decision from experience task. Frontiers in Psychology, 9, 1203. https:// doi.org/10.3389/FPSYG.2018.01203

Traczyk, J., Sobkow, A., Fulawka, K., Kus, J., Petrova, D.G., \& Garcia-Retamero, R. (2018). Numerate decision makers don't use more effortful strategies unless it pays: A process tracing investi- 
gation of skilled and adaptive strategy selection in risky decision making. Judgment and Decision Making, 13(4), 372-381.

Traczyk, J., Sobkow, A., Matukiewicz, A., Petrova, D. G., \& Garcia-Retamero, R. (2019). The experience-based format of probability improves probability estimates: The moderating role of individual differences in numeracy. International Journal of Psychology. https://doi.org/10.1002/ ijop. 12566

Tversky, A., \& Kahneman, D. (1981). The Framing of Decisions and the Psychology of Choice. Science, 211(4481), 453-458.

Tversky, A., \& Kahneman, D. (1992). Advances in prospect theory: Cumulative representation of uncertainty. Journal of Risk and Uncertainty, 5(4), 297-323. https://doi.org/10.1007/BF00122574

Tyszka, T., \& Sawicki, P. (2011). Affective and cognitive factors influencing sensitivity to probabilistic information. Risk Analysis, 31(11), 1832-1845. https://doi.org/10.1111/j.1539-6924.2011.01644.x

Vlek, C. (1984). What constitutes 'a good decision'? Acta Psychologica, 56(1-3), 5-27. https://doi. org/10.1016/0001-6918(84)90004-0

Wegier, P., \& Shaffer, V.A. (2017). Aiding risk information learning through simulated experience (ARISE): Using simulated outcomes to improve understanding of conditional probabilities in prenatal Down syndrome screening. Patient Education and Counseling, 100(10), 1882-1889. https://doi.org/10.1016/j.pec.2017.04.016

Weller, J.A., Dieckmann, N.F., Tusler, M., Mertz, C.K., Burns, W.J., \& Peters, E. (2013). Development and Testing of an Abbreviated Numeracy Scale: A Rasch Analysis Approach. Journal of Behavioral Decision Making, 26(2), 198-212. https://doi.org/10.1002/bdm.1751

Woller-Carter, M.M., Okan, Y., Cokely, E.T., \& Garcia-Retamero, R. (2012). Communicating and Distorting Risks with Graphs: An Eye-Tracking Study. Proceedings of the Human Factors and Ergonomics Society Annual Meeting, 56(1), 1723-1727. https://doi.org/10.1177/1071181312561345

Zacks, R.T., \& Hasher, L. (2002). Frequency processing: A twenty-five year perspective. In P. Sedlmeier \& T. Betsch (Eds.), ETC. Frequency processing and cognition, (pp. 21-36). New York: Oxford University Press.

Zaleskiewicz, T., \& Traczyk, J. (2020). Emotions and Financial Decision Making. In T. Zaleskiewicz \& J. Traczyk (Eds.), Psychological Perspectives on Financial Decision Making, (pp 107-133). Springer. 